additional meeting to be held on April 2, a number of papers will be presented dealing with the various types of continuous wave radio navigational aids which have been developed during recent years.

\section{Summer School in X-Ray Crystallography}

IN recent years the study of materials by means of X-ray diffraction has come to occupy an im. portant place in scientific research both in the universities and in industry. This field of study enters into physical, chemical, metallurgical, mineralogical and biological research. The necessary $\mathbf{X}$-ray technique is, however, highly specialized, and for its proper understanding a fundamental training is required. An attempt to meet the demand for such courses was made at the University of Cambridge by the provision of Summer Schools in the years 1943-46. Although these schools were very successful, they are now to be discontinued; but, if the demand warrants, consideration will be given to their continuation at the Manchester College of Technology under the direction of Dr. H. Lipson. Correspondence should be addressed to the Director of Extra-Mural Studies, University, Manchester, 13.

\section{Cambridge Summer School in Physical Chemistry}

A Summer School on "Some Recent Advances in Physical Chemistry" will be held in the University Department of Physical Chemistry, Cambridge, during August 16-23 inclusive. A course of eighteen lectures will be given by the staff of the Department on the following topics : (1) molecular structure and valency theory (6 lectures); (2) chain reactions (6 lectures); (3) physics and chemistry of rubbing solids (6 lectures). Practical work on these topics will be arranged for those who desire it. Demonstrations will also be given and full opportunity provided for discussion with the lecturers and with those carrying out research in the laboratory. An inaugural lecture will be given on the evening of Saturday, August 16, and the course will finish on the evening of August 23. Arrangements have been made for most of those attending the School to be accommodated in colleges. Applications to attend the School must be received by May 1. Inquiries should be addressed to the Joint Secretaries, Summer School in Physical Chemistry, University Department of Physical Chemistry, Free School Lane, Cambridge.

\section{Pasteur Exhibition}

A Pasteur Exhibition will be held at the Science Museum, South Kensington, London, during April 10-May 26. The exhibition has been arranged and provided, with the assistance of the Cultural Relations Department of the French Foreign Office, by the Palais de la Decouverte in Paris, where it has recently been on show. This institution is devoted to the exposition of modern science, employing for the purpose the most advanced techniques of visual education. The Pasteur Exhibition includes a chronological account of the chemical and biological work of Louis Pasteur on fermentation, putrefaction, the spontaneous generation of life, and on the causative organisms of numerous diseases of men, animals and plants. The results of his work are illustrated by panels dealing with pasteurization in the brewing and other industries, and the raising of disease-free silkworms. A section of the exhibition deals with the Pasteur Institutes established throughout the world for the preparation of serums and vaccines for the combating of disease epidemics.

\section{Fourth International Cancer Research Congress}

Tне Fourth International Cancer Research Congress will be held in St. Louis, Missouri, U.S.A., during September 2-7, 1947. The Union Internationale contre le Cancer having accepted the invitation of the American Association for Cancer Research, the Congress will be held under the joint auspices of these two organisations, with Dr. E. V. Cowdry, professor of anatomy, Washington University School of Medicine, and director of research of the Barnard Free Skin and Cancer Hospital, as president of the Congress. Of the three Congresses that have been held previously, the first was in Madrid, in 1933; the second in Brussels, in 1936; the third in Atlantic City, New Jersey, U.S.A., in 1939. The State Department in Washington having approved of the International Cancer Research Congress, official invitations will shortly be sent to foreign governments. Dr. M. G. Seelig, Barnard Free Skin and Cancer Hospital, St. Louis 3, Mo., is chairman of the Publicity Committee of the Congress.

\section{An Optical-Acoustic Method of Gas Analysis}

Mr. A. Whitaker, chief engineer of Ascot Gas Water Heaters, Ltd., Research Laboratories, Tolworth, Surrey, writes : "The instrument described by Dr. F. I. Callisen in Nature of February 1, p. 167, is being used in these laboratories. It is based on the description published by Dr. Luft-Oppau and has been further developed at our request by the Infra-Red Development Co., Ltd. A working model will be shown by Ascot Gas Water Heaters, Ltd., at the forthcoming Physical Society's Exhibition.

\section{Announcements}

Prof. W. J. DE HAAs, professor of experimental physics and meteorology in the University of Leyden, and Sir John Russell, formerly director of Rothamsted Experimental Station, Harpenden, Herts, have been elected foreign associates of the Paris Academy of Sciences.

The Committee of Privy Council for the Organisa. tion and Development of Agricultural Research has appointed Mr. James Turner, president of the National Farmers' Union, to be a member of the Agricultural Research Council.

Mr. J. F. Foster, formerly registrar of the Univers ity of Melbourne and secretary of the Australian Vice-Chancellors' Committee, has been appointed secretary of the Universities Bureau of the British Empire, on the retirement of Mr. W. B. Brander from that office. Mr. Brander, who has been secretary since 1930, will continue for a while in an advisory capacity.

Mr. N. F. Astrury has been appointed director of research to the Guest, Keen and Nettlefolds group of companies. Mr. Astbury was director of the Research Laboratories of Joseph Sankey and Sons, Ltd., one of the member firms of this group. It is intended that these laboratories shall now become the headquarters of the research organisation of the combine.

THE Research Council of Alberta is offering two fellowships, each of value 1,320 dollars for one year, tenable at the Council's laboratories, University of Alberta, open to graduates in chemistry and chemical engineering. Applications should be sent by air-mail to the secretary of the Council, University of Alberta, as soon as possible. 